\title{
Lesson Learnt from Indonesia Nationalism Making for Contemporary ASEAN Regional Identity Development
}

\author{
Mirah Satria Alamsyah \\ \{satria0809@gmail.com\} \\ Shandong University, China
}

\begin{abstract}
Association of Southeast Asia Nation (ASEAN) is developing ASEAN Regional Identity to bring ASEAN people together also softly integrate ASEAN people in the project of the ASEAN Community. Through this project, ASEAN begins to put the ideational aspect in the quantification. This paper argues regional identity is a social project, the same as Indonesia's creations. The invention of Indonesia as a state is Indonesia's founding father's social project through the nationalism narrations that flourish at that time. On the other hand, regional identity is the narrations that are used to projecting the ASEAN Community. Indonesia has experienced similar but not identical social integrations. This paper argues that Indonesia's experience could contribute to ASEAN regional Identity development. This writing will provide the reason why Indonesia capable to do so. Indonesia is a suitable example of how the various nations shared their identity in the form of Indonesia. Scholars argue that Indonesia practicing integrative nationalism different from Indochina who practicing exclusive nationalism. Tracing Indonesia shared identity making in the process of growing inclusive nationalism will be performed to seek Indonesian contributions to ASEAN regional Identity. If Indonesia could elaborate on their experience to ASEAN regional identity-making Indonesia could strengthen its role in ASEAN.
\end{abstract}

Keywords: ASEAN, Regional Identity, Shared Identity, Indonesian Nationalism

\section{Introduction}

ASEAN has proving itself to be a progressive regional organization. Gradually, ASEAN achieves its goal to become more integrated. The major achievement relates to this is the establishment of the ASEAN Community which launched in August 2015. ASEAN Community consists of three pillars, the Political-Security Community, Economic Community, and SocioCultural Community. All of it aimed to improve ASEAN people's life by following the logic that a more integrated society will lead to fewer burdens in cooperation.

To smoothen out the ASEAN Community, ASEAN set the objective to grow awareness of ASEAN identity. In ASEAN Vision 2020, ASEAN declared that:

"We envision the entire Southeast Asia to be, by 2020, an ASEAN community conscious of its ties of history, aware of its cultural heritage and bound by a common regional identity" [1].

Then, through ASEAN Concord II (Bali Concord II), ASEAN declared that:

"ASEAN shall continue to foster a community of caring societies and promote a common regional identity" [2].

This objective later becomes the responsibility of the ASEAN Socio-Cultural Community. Vejjajiva [3] Prime Minister Kingdom of Thailand (2008-2011) emphasize that the true 
community must be the community of its people. And to achieve it, identity is the key; due to the community is a group without culturally similar people as explained by Acharya [4].

Despite its importance, ASEAN's effort to engaging people through ASEAN identity has less tangible achievement than the other two ASEAN Community pillars. For example, in the economic sector, the ASEAN Free Trade Area (AFTA) loosens up the trade tariffs barrier. It has impacted the positive trend of ASEAN GDP from 2000 to 2018. Or in the political security sector, ASEAN could maintain peace between its member states through the consensus and noninterference norm. One aspect that shows the slow progress of ASEAN Identity is the lack of agreed qualitative indicators to review the progress on building ASEAN Identity. In the 2015 ASCC Scorecard, they only could identify ten quantitative indicators and there are no qualitative indicators. The quantitative indicators such as government expenditure on cultural and information activities to promote ASEAN Awareness year by year; Number of participants involved in culture and information conducted year by year; and Number of ASEAN activities involved in culture and information conducted year by year [5]. As criticized by Jonsson [6], regionalism often measures through quantifiable indicators such as level of interaction. Meanwhile, the need to include qualitative indicators could not be abandoned. On the other hand, ERIA's (Economic Research Institute for ASEAN and East Asia) did the qualitative approach. They conduct comprehensive research on ASEAN people's perceptions of the ASEAN community [7]. People's perceptions of ASEAN could be one of the qualitative indicators to look for ASEAN identity progress.

These explanations did not mean that ASEAN failed to realize ASEAN identity, but it is slow in progress. The paper argues that ASEAN could take some lessons from Indonesian nationalism building relating to their effort to raise awareness of ASEAN identity. This paper is aware that nationalism and regional identity could not simply put in the equation. Then, the paper will first find out where nationalism and regional identity overlap. Next, the writer will provide some events from the Indonesian nationalism building that could become a lesson for ASEAN identity building.

\section{Method}

This is qualitative research. This paper uses literature studies as a method. Data collection has been done by compiling the academic journal, book, articles, and website related to the topics.

\section{Result and Discussion}

\subsection{Nationalism and Regional Identity}

The concept of identity provides an understanding of how nationalism and regional identity could complement each other. Identity through its functional definition is the actors understanding about 'self' that leads to the identification and labeling of what himself is. Identity also could identify others by seeing the attribute that others 'embedded' to them. Further, Alexander Wendt [8] explains that identity constitutes by both internal and external structures. When the internal structure is a self-understanding over 'self', while the external structure is the structure outsides 'self' where 'self' embedded [8]. Identity is important due to its ability to create the objective of the actor. Both nationalism and regional identity create awareness about people's identity in a certain 
level of community. Both attempts to produce a shared identity between different background subjects. A further explanation about this will be put in the specific sub-chapter below.

\subsubsection{Nationalism}

Nationalism here is treated as identity. Nationalism defines as people's sense of belonging to a nation-state where they are embedded. However, this definition is not enough to categorize nationalism as an identity. Which aspect of nationalism that makes its identity? The explanations come from where nationalism originated. Knight [9] explains that nationalism is in one package with identity and territory. When the territory becomes a basis of social-political group inhabit, identity is the label to identify the social-political group that lives in that territory. This identification supported by the recognition of the nation-state system along with state selfdetermination notion brings nationalism to grow [9]. Cronin [10] explains self-determination means the nation-states system should respect the idea of international borders based on nationality, the state system play role only inside its border.

Nationalism is born when there is clear identification to which nation-state people belong to. By doing this, nationalism bounding to the specific social-political group, the specific territorial boundaries, and the specific self-determination right where they are entitled. These conditions make nationalism as an identity, it could identify 'self' and 'other'.

In relation to regional identity, nationalism is limited to the territory of nation-states; while regional identity aims for the same sense of belonging expand to the region.

\subsubsection{Regional Identity}

Baba [11] explains that regional identity comes from the consciousness of inhabitant that being a part of a particular region. It shaped the sense of 'we-ness' and 'otherness'. These senses make people in society socially bounded. Deutsch, as cited in Acharya [4], believes that 'identification' in the case of state regional integrations as one of the instruments, with 'identification' being defined as 'the deliberate promotion of processes and sentiments of mutual identification, loyalties, and 'we'-feelings [4]. Identification is important due to its ability to strengthen the cooperation between nation-states through the attachment of people in their region [12]. Paasi [13] also expresses that regional identity importance is to make of regions as socialpolitical spaces.

If we treat nationalism as an identity, there is not much difference between nationalism and regional identity. The subject, objective, and capability have something in common. Except for the territorial range were both embedded. Nationalism is the people's sense of belonging limited to their nation-state territory. Meanwhile, regional identities want to broaden this sense of belonging to the regional level.

Regional identity and nationalism a bit different due to the sense of belonging to the nationstate is more powerful than to the regional level. Because the Nation-state system is hierarchical structure relations between government and citizen, who possess the ability to enforce the policy to the citizen. Meanwhile, regional identity is work under the anarchical structure relations between sovereign nation-states; there is no higher authority between them, only consensus or agreement that acceptable. This structure of relations explains that people in the level of the nation-state have a social obligation also a legal obligation to followed voluntary or not to nation-states identity. In contrast, at the regional level identity adapt only through interactions and social awareness. In the ASEAN case, Connors said, 'the pillar of ASEAN is voluntarism, not legalism' [14].

Previous explanations show that it is possible to put nationalism and regional identity in the equation, by putting them in the conceptual framework of identity. 


\subsection{Indonesia Nationalism Building}

It needed to be understood that by putting sub-title Indonesia nationalism building, writers agree that nationalism in Indonesia's history is constructed. Benedict Anderson criticizes that many Indonesian still believe that Indonesia is an "inheritance" [15]. It means for Indonesian, Indonesia exists far before it was declared on 8 August 1945. The emphasis on Indonesia as a social project is to clarify where writers will bring the argument.

Indonesia is a heterogeneous country and the most populous country in Southeast Asia. Mustansyir [16] emphasizes that diversity in Indonesia is the concrete reality. Before the nationstates period, the landscape of Nusantara inhabits by kingdoms, ethnic communities, and tribal communities before it legally becomes Indonesia. Before their loyalty to Indonesia, the inhabitant is already showing the loyalty of their previous culturally homogenous social-political community. However, historical fact shows the emergence of nationalism leads to a struggle for independence in Indonesia and uniting that primordial social-political community to Indonesia.

The process of unifying heterogeneous society through nationalism ideas will be discussed here. From the reading that writers did, Indonesian nationalism was born from two selfidentification process, subject identification, the objective identification which leads to collective action.

\subsubsection{The Subject Identification}

Identification over the subject or self is the core of identity discussion. Pre-Indonesia raising awareness about themselves started with the growth of the national movement. Kartodirdjo [17] explains nationalism in its formative stage (the emergence of national movement) only bringing the subjective element not yet the objective element. The subjective element is the consciousness of people about themselves.

In the case of Indonesia, the idea that growth is the group-consciousness, we-sentiment, corporate wills, and other ideas that led to unity [17]. The objective element, such as state creation or the need for the government comes later. Lohanda [18] explains the early pre-Indonesia national movement Boedi Oetomo, Sarikat Islam and Indische Partij did not aim to create a nation. However, all of them had already shown the value of nationalism during their movement [18]. Moreover, Perhimpunan Indonesia who created later been described by Kroef [19] is the first unambiguous declarations of Indonesia identity. Due to the adaptation of the term Indonesia that gives clear nationalism nuances.

All national movement organizations that have been mentioned before important due to their ability to shows whom they represent. In general, are the indigenous colonized people in Indische. In particular, Boedi Oetomo representing the educated Javanese; Sarekat Islam representing the peasant, trader, and Islamic people in the Indische; Perhimpunan Indonesia represents the scholars; Indische Partij represents all indigenous Indiche residents. These movements pioneer the idea of uniting multiethnic people in pre-Indonesia.

The subject identifications also could be seen in the Youth Pledge 1928 (Sumpah Pemuda). In that pledge, the representation of different cultural youth (who decide to join) proclaimed themselves to be one nation, one language, one motherland, (satu bangsa, satu bahasa, satu tanah air) Indonesia. They also create the symbolic identification instrument, such as a motto, flag, and national anthem. This pledge is seen as the pioneer of unity in Indonesian nation-building. Even though this pledge still limited due to the representations did not represent all cultural community as modern Indonesia, indeed they trigger the process of Indonesia self-identification. 
Identity is dynamic, it is defined and redefined based on the change in the historical, social, economic, political aspects. For example, previously East Timor is part of Indonesia but then becomes a country. Nordholt [20] emphasizes that Indonesian especially its cultural identity is an unfinished project because ideas and ideals were projected into the future.

These portraits of the event show that Indonesia goes through self-identification phases. As a result, unity about identity is established.

\subsubsection{The Objective Identification}

After subject identification, Indonesia comes to the phases of objective identification. What will a community of people do if they possess such an identity? Wendt [8] explains that identity is the basis of intention. Moreover, intention and objectives are related to each other. The idea such as anti-colonialism, self-determinations, and independence states is the intention/objectives that occur as the result of possessing nationalist identity.

Perhimpunan Indonesia provides an example of early Indonesia national movement objectives. Through print media Indonesia Merdeka in 1924/25, they set three principles to raise national movement awareness [17]:

a. The liberation of Indonesia through self-conscious nationalistic mass action while relying on its own forces;

b. All levels of the community must participate;

c. Intensification of conflict between colonizer and colonized people.

In Kartodirdjo's [17] understanding, these principles' intrinsic aim is to change power relations. Through these principles, PI presents the objectives of possessing nationalism in Indonesia's experience.

Nationalism has many objectives, depends on the background of nationalism. The background of Indonesia nationalism could be described as anti-colonialism and selfdetermination type of nationalism. Purwanto [21] explains that Indonesian nationalism was constructed as the antithesis to the Dutch colonial domination. So, the first objectives in Indonesia's experience are the diminishing of Dutch subjugation.

The next objective of nationalism in Indonesia is self-determination. In a simple definition, self-determinations are the right of an identified nation to decide for themselves. Moreover, according to Cronin [10], self-determination means each state should respect the idea of international borders based on nationality, the state system play role only inside its border. Meanwhile, Gottman in Knight [9] said that the self-determination notion means that every state should be allowed to make its own system of law. The creation of Indonesia as a state is the result of the self-determination objective. It created internally through national movement also contributed by external factors such as the trend of the independence nation-state system.

The final shape of Indonesian nationalism objective identification could be seen in the Indonesian proclamation of independence. Indonesia declared that it has achieved independence and will transfer the ruler to Indonesian. It confirms two objectives that are explained before.

If the subject identification tracing back the past value that makes them belong together, objective identification gives them the image of the future. The elaboration of both will create a shared-identity or even collective action.

\subsection{ASEAN Regional Identity in the Making}

ASEAN Regional identity is the idea that aims to create we-feelings among ASEAN people. Indonesia's identification over itself and its objective through nationalism provide some lessons for 
ASEAN regional identity-making. Also shows some weakness in ASEAN regional identity. It needs to be clear that despite the similarity of the unity idea between Indonesian nationalism and ASEAN regional Identity, ASEAN did not want to disturb the firm sovereignty of the national level. As they state in ASEAN Vision 2020.

"We see vibrant and open ASEAN societies consistent with their respective national identities, where all people enjoy equitable access to opportunities for total human development regardless of gender, race, religion, language, or social and cultural background" [1].

Applying ASEAN Identity is specifically the aim of the ASEAN Socio-Cultural Community framework. As cited in ASCC Blueprint for 2025 that declared in 2015, the strategic measures to empowered people and strengthen institution is to:

"Promote ASEAN awareness among government officials, students, children, youths, and all stakeholders as part of building ASEAN identity" [5].

Meanwhile, ASEAN identity based on ASEAN secretariat 2019 is defined as:

"The basis of Southeast Asia's regional interests. It is our collective personality, norms, values, and beliefs as well as aspirations as one ASEAN Community... The strategic objective is... to create a sense of belonging, consolidate unity in diversity and enhance deeper mutual understanding among ASEAN member countries about their culture, history, religion, and civilization..." [22].

Toward the ASEAN Identity definition, Vejjajiva [3] Prime Minister Kingdom of Thailand 2008-2011 address that there is a problem with the definition, he said that

"ASSC lacks a clear underpinning principle that supports them (the objective of ASCC, one of them is ASEAN regional identity) ... The blueprint itself has not set out in holistic terms what kind of a community ASEAN wants to be.... It has not spelled out what the ASEAN identity is or should be" [3].

Putri [23] and Saehu [24] also argue, even though many ASEAN Documents provide terminology about ASEAN identity, no document defines and legally adopted by ASEAN. ASEAN has a problem with what they imagined as ASEAN identity.

Scholars criticize ASEAN identity, not only in the absence of ASEAN identity clear definition, but they also see it as skeptical. Scholars criticize that, ASEAN is the elite project without accommodating people in ASEAN [25][6]. Shaun Narine argues ASEAN Identity is overwhelming, national identity is more influential [12].

Collective self-imagination to building a community is important. Meanwhile, ASEAN did not possess such a collective identity. ASEAN consists of a different unit of collective identity in the shape of nation-states who cooperate toward each other. This is the result of unclear identification of the subject and objectives of regional identity. Putri [23] emphasizes that ASEAN needs to balancing the constructed value with ascribed inherited value. For example, in the Indonesia experience, the ascribed inherited value through the historical narration about Sriwijaya and Majapahit kingdom along with the constructed value about builds a country help to grow collective identity among people in the pre-independence period.

Furthermore, Indonesia nationalism is a bottom-up process, while ASEAN regional identity is an up-bottom process. Even though Indonesia nationalism was initiated by the educated Indonesian it not started from the stakeholder at that time, which is the Dutch government. Meanwhile, ASEAN regional identity is coined by the elite and stakeholders in ASEAN. Sidel [26] said political struggle could be constructing from the bottom-up process through revolution or top-down process through social engineering. Indonesia nationalism was achieved through revolutions, where ASEAN still in the social engineering process. 
About the regional identity awareness, ERIA's (Economic Research Institute for ASEAN and East Asia) shows there is a positive result related to ASEAN identity. Through FGD that they did, they got half of the correspondent (which are a student) feel that they 'very much' ASEAN citizen. Despite this good news, they also suggest that ASEAN needs to be less elitist to more connect to ASEAN people. The feelings as ASEAN citizens are only based on geography and ethnicity closeness; which is supported by the removal of travel visas within the region. They further explain that people did aware of ASEAN, but their awareness is limited. ERIA's explained that $87 \%$ of their respondents did aware of ASEAN, but limited only on ASEAN's Economic pillars [7]. There is a problem in distributing the idea of national identity to average people's level. ASEAN regional identity is the product of regional state relations, where Indonesia nationalism is the product of people relations. As a result, Indonesian nationalism is closer to Indonesian people than regional identity to ASEAN people.

In the previous explanation, the comparison of the Indonesian nationalism building and ASEAN regional identity building provides three aspects that contrast and could become a lesson. First, ASEAN regional identity is lack identification. Second, there is a problem in transfers ASEAN identity to the people level. Then we come to the last comparison, the different reasons for unity. World war has proved that a common enemy provides unity. It happens in Indonesia's experience of colonialism. Meanwhile, in ASEAN identity the unity reason is the projection of a bright future. Axelrod and Keohane [27] has explained that the image of the future is the forces of regional cooperation. The problem is the past is felt and can be clarified, while future image creating enthusiasts but not yet proven. In my understanding, the experience along with the antagonistic of others will provide more effective unity. Meanwhile, the image of the future will only create more cooperative different units towards others.

\section{Conclusion}

ASEAN Regional identity and Indonesian nationalism could not merely put on the equation. To some degree, there is a difference that could become a lesson for the ongoing process of ASEAN regional identity building. From the comparison, this paper concludes that ASEAN needs to redefine ASEAN Identity; there is the problem of transferring ASEAN identity to people level; the reason to become unity needs to focus on the historical experience that explains the commonalities of ASEAN people. Writers realize that this paper still on the surface. However, it is hoped that this paper could be a baseline for further research.

\section{References}

[1] ASEAN Secretariat, “ASEAN Vision 2020,” Assoc. Southeast Asia Nations, 2012.

[2] ASEAN Secretariat, "Declaration of ASEAN Concord II (Bali Concord II)," Assoc. Southeast Asian Nations, 2012.

[3] A. Vejjajiva, "The Critical Importance of Socio-cultural Community for the Future of ASEAN," ASEAN@50 Build.ASEAN Community Polit. Socio-cultural Reflections, pp. 346-357, 2017.

[4] A. Acharya, "The evolution and limitations of ASEAN identity," Build. ASEAN Community, vol. 186, p. 25, 2017.

[5] ASEAN Secretariat, 2015 ASEAN Socio-Cultural Community (ASCC) Scorecard. Jakarta: ASEAN Secretariat, 2015.

[6] K. Jönsson, "Unity-in-diversity?: regional identity-building in Southeast Asia," J. Curr. Southeast Asian Aff., vol. 29, no. 2, pp. 41-72, 2010. 
[7] T. T. Vo and D. A. Nguyen, "What Does ASEAN Mean to ASEAN Peoples? Survey Findings from Viet Nam," Voices of ASEAN, p. 309, 2017.

[8] A. Wendt, Social Theory of International Politics. New York: Cambridge University Press, 1999.

[9] D. B. Knight, "Identity and territory: geographical perspectives on nationalism and regionalism," Ann. Assoc. Am. Geogr., vol. 72, no. 4, pp. 514-531, 1982.

[10] B. Cronin, "Community under anarchy," Transnatl. Identity Evol. Coop. New York, 1999.

[11] G. Baba, "Regional Commonalities and Regional Identities: Forging a Normative Understanding of Southeast Asian Identity," J. Curr. Southeast Asian Aff., vol. 35, no. 1, pp. 91-121, 2016.

[12] S. Narine, "The English school and ASEAN," Pacific Rev., vol. 19, no. 2, pp. 199-218, 2006.

[13] A. Paasi, "Region and place: regional identity in question," Prog. Hum. Geogr., vol. 27, no. 4, pp. 475-485, 2003.

[14] M. K. Connors, R. Davison, and J. Dosch, The New Global Politics of the Asia-Pacific: Conflict and Cooperation in the Asian Century. Routledge, 2017.

[15] B. R. Anderson, "Indonesian nationalism today and in the future," Indonesia, pp. 1-11, 1999.

[16] R. Mustansyir, "Kebangsaan Indonesia: Reaktualisasi Nasionalisme dalam Menyongsong Abad XXI," J. Filsafat, vol. 1, no. 1, pp. 167-186, 1997.

[17] S. Kartodirdjo, "Some Problems on the Genesis of Nationalism in Indonesia," J. Southeast Asian Hist., vol. 3, no. 1, pp. 67-94, 1962.

[18] M. Lohanda, "Nasionalisme Indonesia dan Pembentukan Nasion," Antropol. Indones., pp. 86-93, 2019.

[19] J. M. Kroef, "Indonesian Nationalism Reconsidered," Pac. Aff., vol. 45, no. 1, pp. 42-59, 1972.

[20] H. S. Nordholt, "Indonesia in the 1950s: Nation, modernity, and the post-colonial state," Bijdr. tot taal-, land-en volkenkunde/Journal Humanit. Soc. Sci. Southeast Asia, vol. 167, no. 4, pp. 386-404, 2011.

[21] B. Purwanto, "Memahami Kembali Nasionalisme Indonesia," J. Ilmu Sos. dan Ilmu Polit., vol. 4, no. 3, pp. 243-264, 2001.

[22] L. Maramis, "Integrative Chapter for Volume Four: ASEAN's Socio-cultural Community," Build. ASEAN Community, p. 179, 2017.

[23] F. R. Putri, "Identitas ASEAN: Membumikan ASEAN ke Akar Rumput," Masy. ASEANMenuju Masy. ASEAN 4.0, pp. 36-39, 2019.

[24] R. J. Saehu, "Soliditas dan Solidaritas dalam Keberagaman dan Kreativitas Budaya yang Berkelanjutan untuk Memperkuat Identitas ASEAN," Masy. ASEAN Tahun Kebud. ASEAN, pp. 4-5, 2019.

[25] M. Davies, "An agreement to disagree: the ASEAN Human Rights Declaration and the absence of regional identity in Southeast Asia," J. Curr. Southeast Asian Aff., vol. 33, no. 3, pp. 107-129, 2014.

[26] J. T. Sidel, "The Fate of Nationalism in the New States: Southeast Asia in Comparative Historical Perspective,” Comp. Stud. Soc. Hist., vol. 54, no. 1, pp. 141-144, 2012.

[27] R. Axelrod and R. O. Keohane, "Achieving cooperation under anarchy: Strategies and institutions," World Polit., vol. 38, no. 1, pp. 226-254, 1985. 